\title{
Infrared Absorption Spectra of the Liquid Butenes and 1,3-Butadiene
}

\author{
By E. Carroll Creitz and Francis A. Smith
}

\begin{abstract}
The infrared absorption spectra, from 1 to 15 microns, of 1-butene, 2-methylpropene (isobutene), cis-2-butene, trans-2-butene, and 1,3-butadiene have been recorded in the liquid phase under pressures sufficient to liquify them at room temperature.

The spectra of the same samples in the vapor phase have been recorded and are presented for comparison.

A rock-salt prism was used for the range from 2 to 15 microns. The spectra of the same samples, both liquid and vapor, were obtained at higher resolution over the range from 1 to 4.2 microns using a lithium fluoride prism, and are presented for comparison.

The spectra obtained from the liquid phase provide data for the development of a procedure for the analysis of liquid plant streams by spectrometric methods.
\end{abstract}

\section{Introduction}

One of the factors limiting the accuracy of the analysis of mixtures of the butenes and butadiene has been the difficulty of obtaining a sample for analysis in the vapor phase that is representative of the composition of the liquid in the "bomb" in which samples from liquid plant streams are collected. This difficulty results from the variable partial fractionation that takes place on vaporization. ${ }^{1}$ The difficulty might be largely eliminated in the case of infrared spectrometric analysis by the use of absorption cells for liquids that are tight at pressures high enough to permit analysis of the liquid at room temperature, based on spectra of the pure constituents in the liquid phase.

Cells for liquids, with rock-salt windows, tested to $35 \mathrm{lb} /$ in. $^{2}$ gage, have been described by the present authors. ${ }^{2}$

The spectra of five of the constituents of such mixtures, 1-butene, 2-methylpropene, cis-2-butene, trans-2-butene and 1,3-butadiene have been recorded in the liquid phase from 2 to $15 \mu$ with an $\mathrm{NaCl}$ prism and from 1 to $4.2 \mu$ with an LiF prism.

The spectra of these hydrocarbons in the liquid phase apparently have not previously been re-

\footnotetext{
${ }_{1}$ Vernon H. Dibeler and Fred L. Mohler, J. Research NBS 39, 149 (1947) RP1818.
}

${ }^{2}$ Francis A. Smith and E. Carroll Creitz, Analytical Chem. In press. corded, nor their spectra (liquid or vapor) were previously available, as resolved by the LiF prism, in the series distributed by American Petroleum Institute Research Project $44 .^{3}$

\section{The Spectrometer}

The instrument used was a model $12 \mathrm{~B}$ PerkinElmer infrared absorption spectrometer. The direct-current thermocouple signal was fed through a General Motors breaker-type amplifier to a Brown Electronik strip chart recorder, operating on a stabilized-power supply. The Globar source was operated at about 210 watts from a separate stabilizer.

Prisms of $\mathrm{NaCl}$ and $\mathrm{LiF}$ were used in the present work.

The peak-to-peak electrical noise, a factor affecting the photometric accuracy, has been reduced to about \pm 1 percent at a sensitivity of $0.1 \mu \mathrm{v}$ for full scale on the chart. ${ }^{4}$

In normal operation, as for the present work, the sensitivity is reduced to $0.6 \mu \mathrm{v}$ for full scale, and the slits are changed manually in steps according to a schedule designed to keep the background energy between 40 and 90 on the linear chart scale. The spectrum is scanned from long toward short

${ }^{3}$ Catalog of Infrared Spectral Data issued by the American Petroleum Institute Research Project 44 at the National Bureau of Standards. ${ }^{4}$ E. Carroll Creitz, Analytical Chemistry 20, 707 (1948). 
wavelengths at from 1 to 8 minutes per revolution of the wavelength micrometer drum, the lower rates being used at short wavelengths where the resolution is affected by the speed of scanning, and where water vapor or carbon dioxide absorptions appear in the background. These absorptions are reduced by flushing the spectrometer housings with dry nitrogen. The background record and sample absorption are recorded successively for each section of the spectrum without changing the slit. A slight overlap between sections provides good continuity of photometric values from section to section at different slit settings.

Adjustment for the energy absorbed and reflected by the cell windows was made by the use of blank cells (a double thickness single window for the liquids), and the effects of stray energy have been minimized by the use of glass and LiF shutters.

The wavelengths of sharp bands are accurate to between 0.01 and $0.02 \mu$ and adjacent relative values of percentage transmittance to about 1 percent except when occasional departures from linearity of the zero drift may result in absolute errors of as much as 5 percent or errors in relative values between the ends and the central portion of a section of spectrum of a like amount. The magnitude and departures from linearity of the zero drift were minimized by automatically maintaining the air temperature at the spectrometer constant to $\pm 0.2 \mathrm{deg} \mathrm{C}$.

The resolution attained under the present conditions represents a definite improvement, in the 2 - to $6-\mu$ range, over that attained by instruments from which spectra for the compounds studied have been made available to the present time by American Petroleum Institute Research Project 44 (see footnote 3 ).

\section{Source and Purity of the Butenes and Butadiene}

The 1-butene, 2-methylpropene, cis-2-butene, and trans-2-butene were Phillips Petroleum Company's Research Grade, certified by this Bureau from measurements of freezing points, as having the following purities respectively: $99.88 \pm 0.2$ percent, $99.30 \pm 0.20$ percent, $96.18 \pm 0.15$ percent, and $98.92 \pm 0.10$ percent.

The 1,3-butadiene was Phillips Research Grade material that had been stored for about 4 years. The material used in this work was purified by two distillations through a dedimerizing column developed at the Sun Oil Co. ${ }^{5}$ Subsequent analysis by mass spectrometer showed the following impurities: $n$-butane, 0.06 percent; 2-methylpropane (isobutane), 0.05 percent; $n$-propane, 0.05 percent; propylene, 0.09 percent; and total butenes 0.44 percent; totaling 0.69 percent and giving $1,3-$ butadiene by difference, approximately 99.3 percent.

The samples were protected from contamination during measurement by transfer to the absorption cells through $1 / 8$-in. copper tubing. Connections were made with stainless steel cone to brass cylinder fittings and the flow controlled by metal needle valves with saran packing. ${ }^{6}$

\section{Procedure for Transferring Sample}

The cylinder in which the sample was obtained was fitted with an adapter and a needle valve to control the flow. Near the cylinder end of the sample line was a tee connecting to a pressure gage. The other end was connected to one side of the cell. A needle valve was connected to the other side of the cell, the outlet of the valve being connected to a tube leading to an air exhaust vent or through a drying trap to a water aspirator pump as required.

With the needle valive at the cell outlet connected to the pump and that near the cylinder open, the cell and line up to the cylinder valve were evacuated. Both needle valves were then closed, the cylinder valve opened, and vapor admitted to the line and cell by opening slightly the needle valve near the cylinder. Evacuation and filling were performed three times, after which the cell outlet valve was connected to the vent. The temperature of the cylinder and gage were raised slightly by radiation from an electric lamp with reflector until the pressure of the vapor was sufficient to produce condensation in the cell at the existing temperature. Bubbles were vented through the outlet needle valve until the cell filled completely and remained so. Of course when analyzing liquid samples of mixtures from plant streams the connection to the sample container would be made at the bottom and the entire line and cell filled with liquid, no vapor phase being present between container and cell.

${ }^{5}$ James L. Jezl and Charles P. Hablitzel, Analytical Chem. 21, 1046 (1949).

${ }^{6}$ Connections and needle valves developed at this Bureau by H. F. Stimson. Unpublished. 
The connecting tubing was sufficiently flexible to permit ready interchange of the filled cell and the blank cell in the spectrometer ways. The temperature recorded was that of the air at the spectrometer at the time of recording the spectrum. Spectra were initially recorded at $25.2^{\circ} \mathrm{C}$, but, when it was found that the vapor pressure of the lower boiling samples exceeded the safe cell pressure at that temperature, the air temperature was set at about $21.6^{\circ} \mathrm{C}$ where the remainder of the work was done.

\section{Results}

Observed transmittances in percentage have been plotted with respect to wavelengths and wave number, and the resulting spectrograms are presented in pairs in figures 1 to 10 , liquid and vapor spectra for each substance being adjacent to facilitate comparison.

Cells of three different thicknesses were used for the liquid samples, and three or more pressures were used in the case of the vapor samples. This placed most of the transmittance minima between 20 and 80 percent with one cell or another.

Differences, the significance of which will not be considered in this paper, appear between the liquid and vapor spectra of each sample. In general the spectrum of the liquid appears to be simpler than that of the vapor, and in numerous instances the member of shorter wavelength of what appears as a doublet in the vapor spectrum is much weaker or missing in the spectrum of the liquid. However, there appear to be a few instances in which the member of shorter wavelength is stronger in the liquid than in the vapor.

The band at $14.8 \mu$ in liquid trans-2-butene but not in the vapor (fig. 4), is undoubtedly the result of absorption by the cis-isomer, which has its strongest absorption at this wavelength. Since it boils at a higher temperature than the trans-isomer, it could be expected to be present in higher concentration in the liquid than in the vapor phase of trans-2-butene. The observed intensity of the band is in good agreement with the probable concentration $(1 \%)$ of the cis-isomer in the sample.

The different intensities of the several components of the $\mathrm{C}-\mathrm{H}$ band resolved by the $\mathrm{LiF}$ prism in the spectra of the liquid as compared with those of the vapor may be of interest in connection with the use of this band for analytical purposes, as reported by Saier and Coggeshall. ${ }^{7}$

${ }^{7}$ Eleanor L. Saier and Norman D. Coggeshall, Analytical Chem, 20, 812 (1948). 


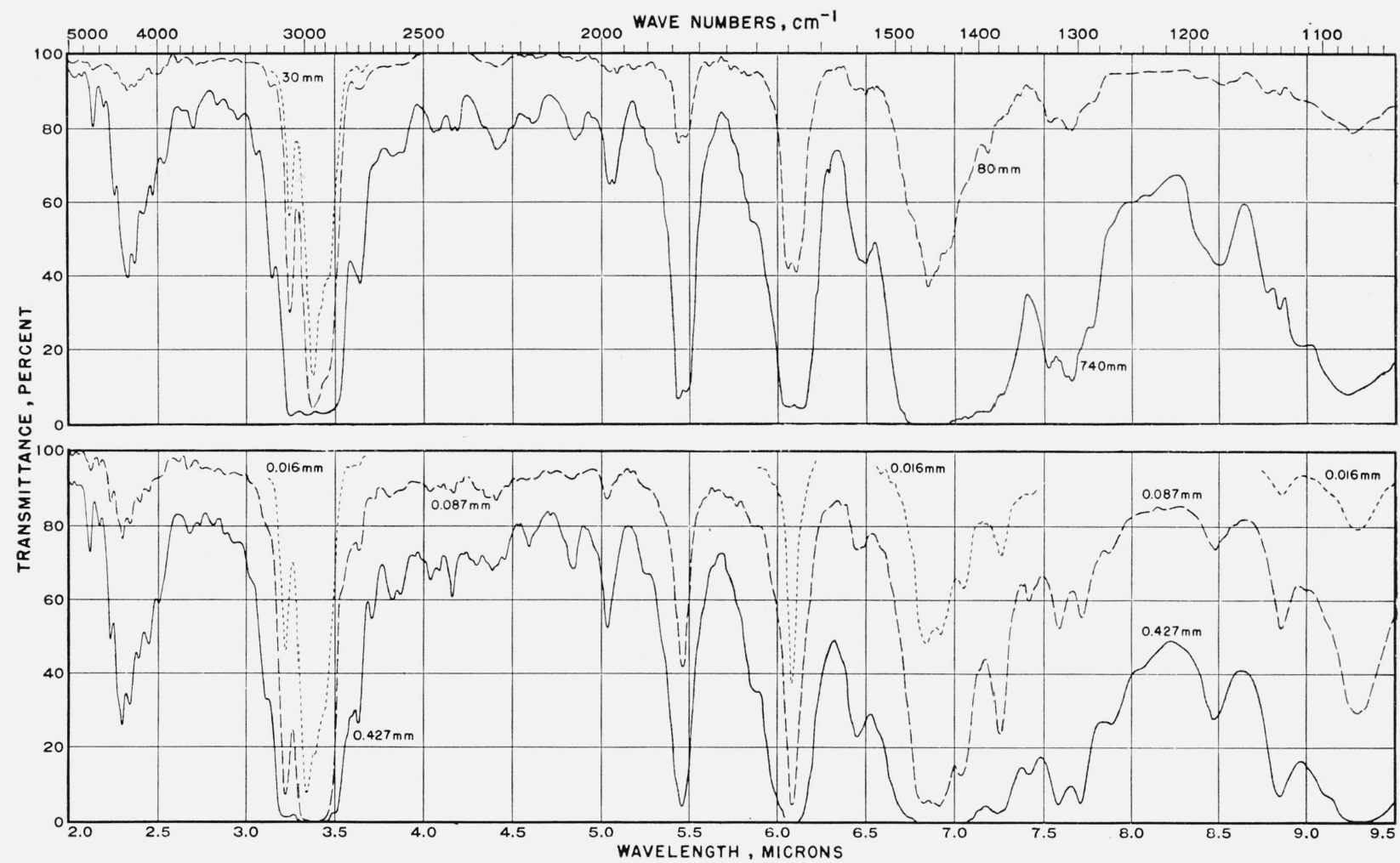

FIGURE 1. Infrared absorption spectrum of 1-butene.

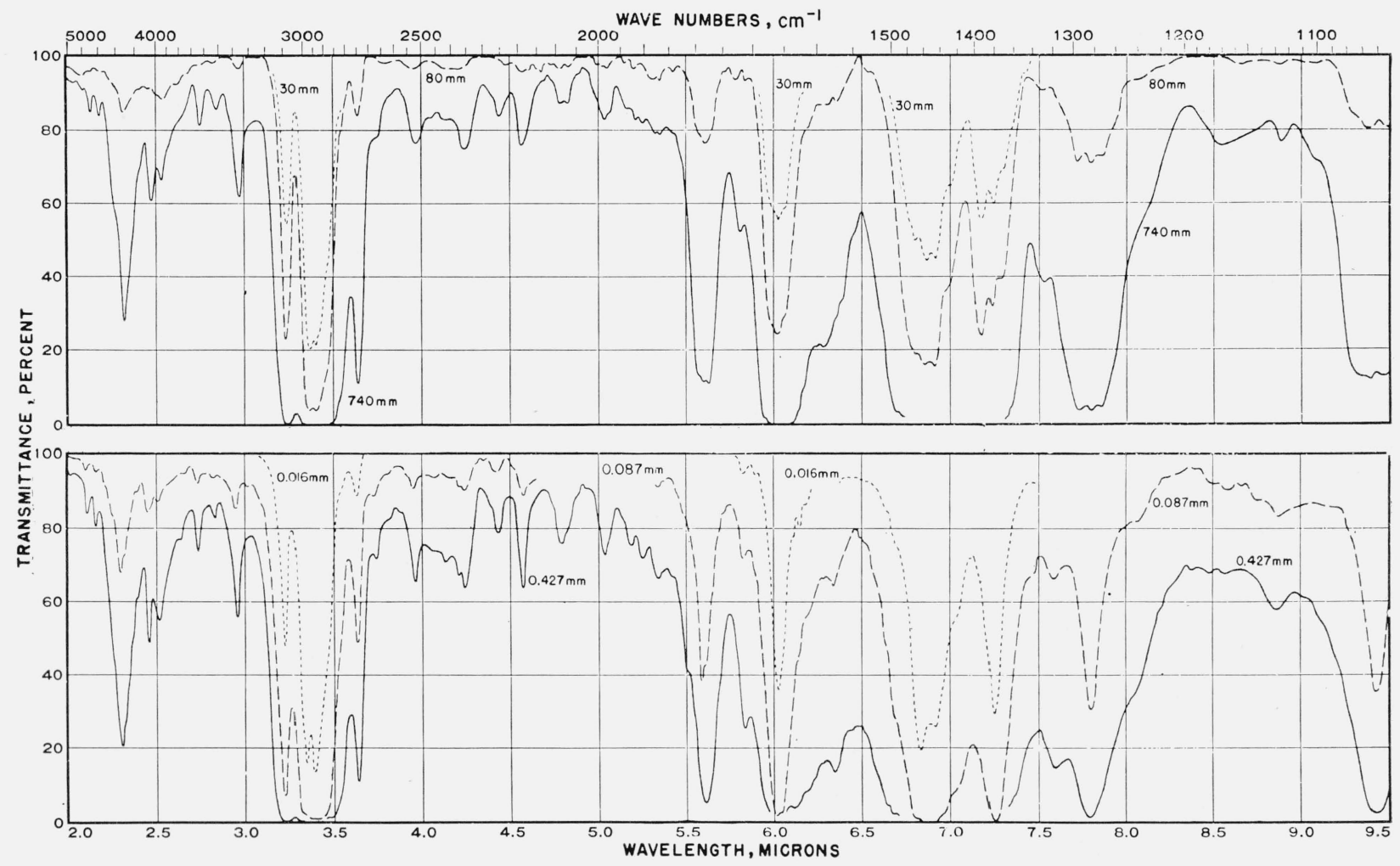

FIGURE 2. Infrared absorption spectrum of 2-methylpropene (isobutene). 

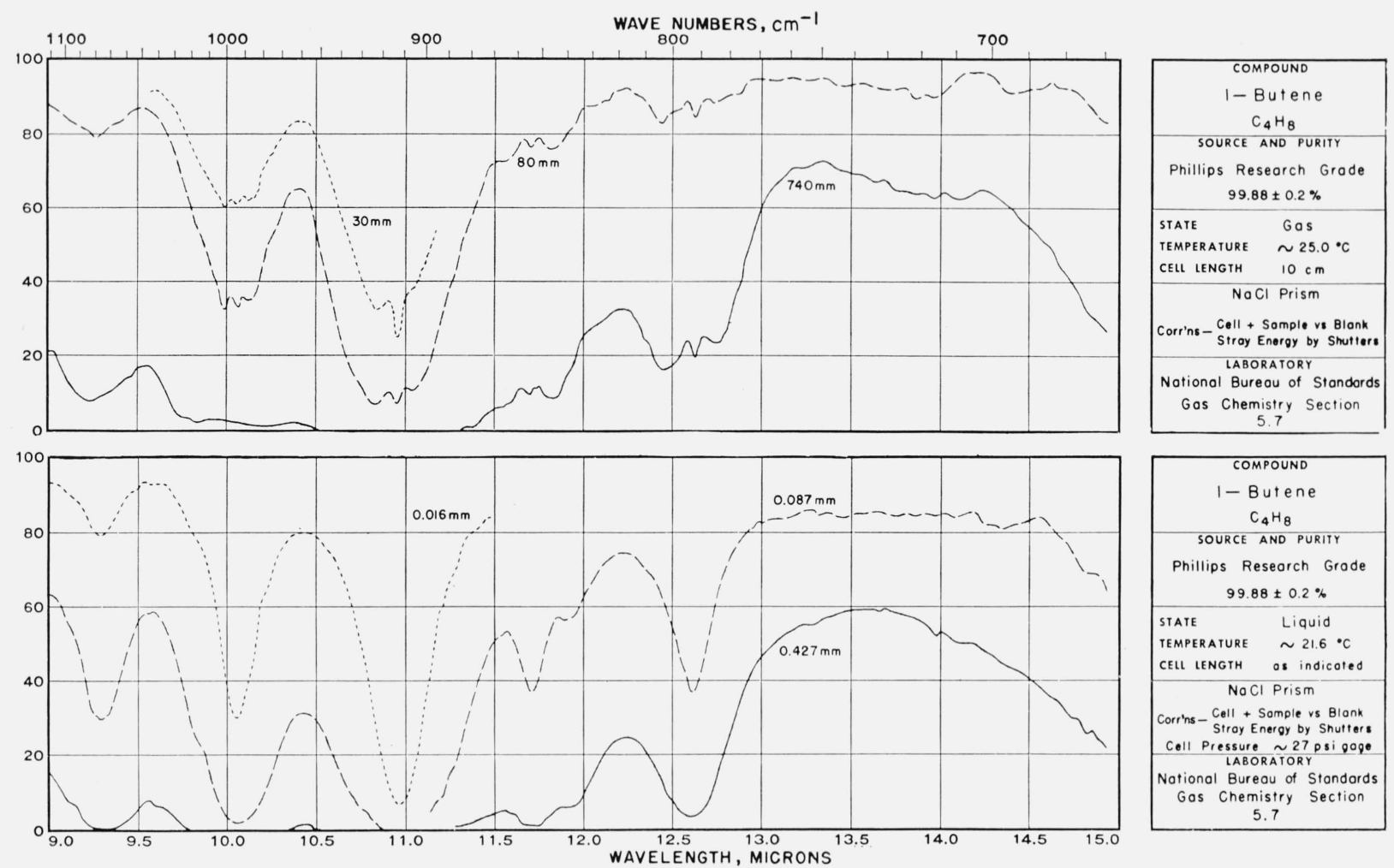

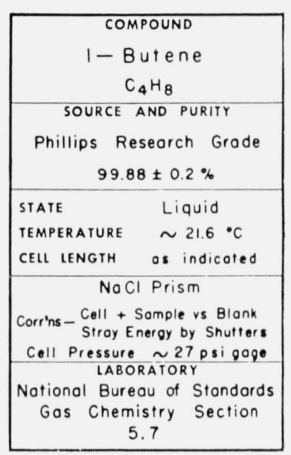

Figure 1-Continued.
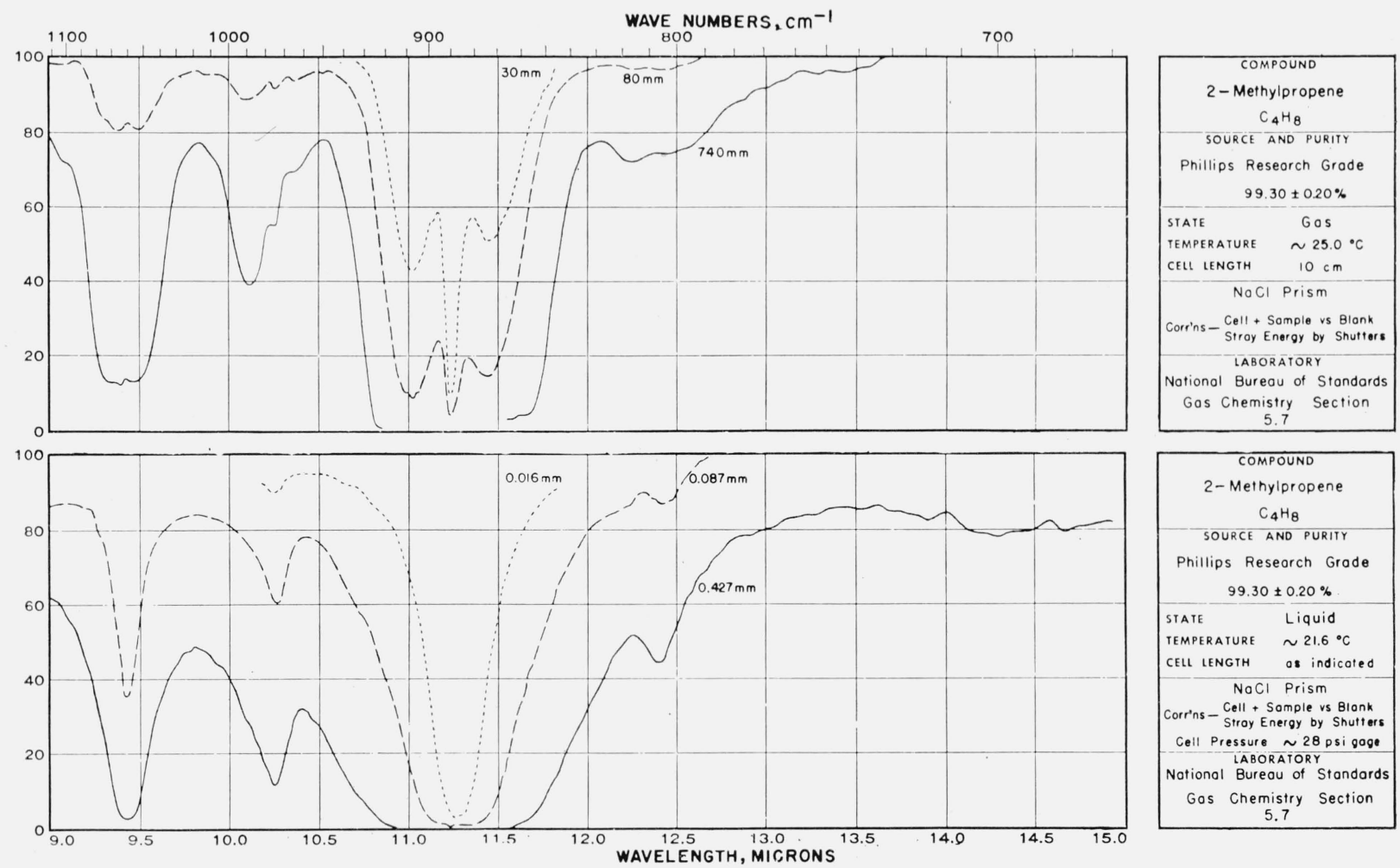

Figure 2-Continued. 


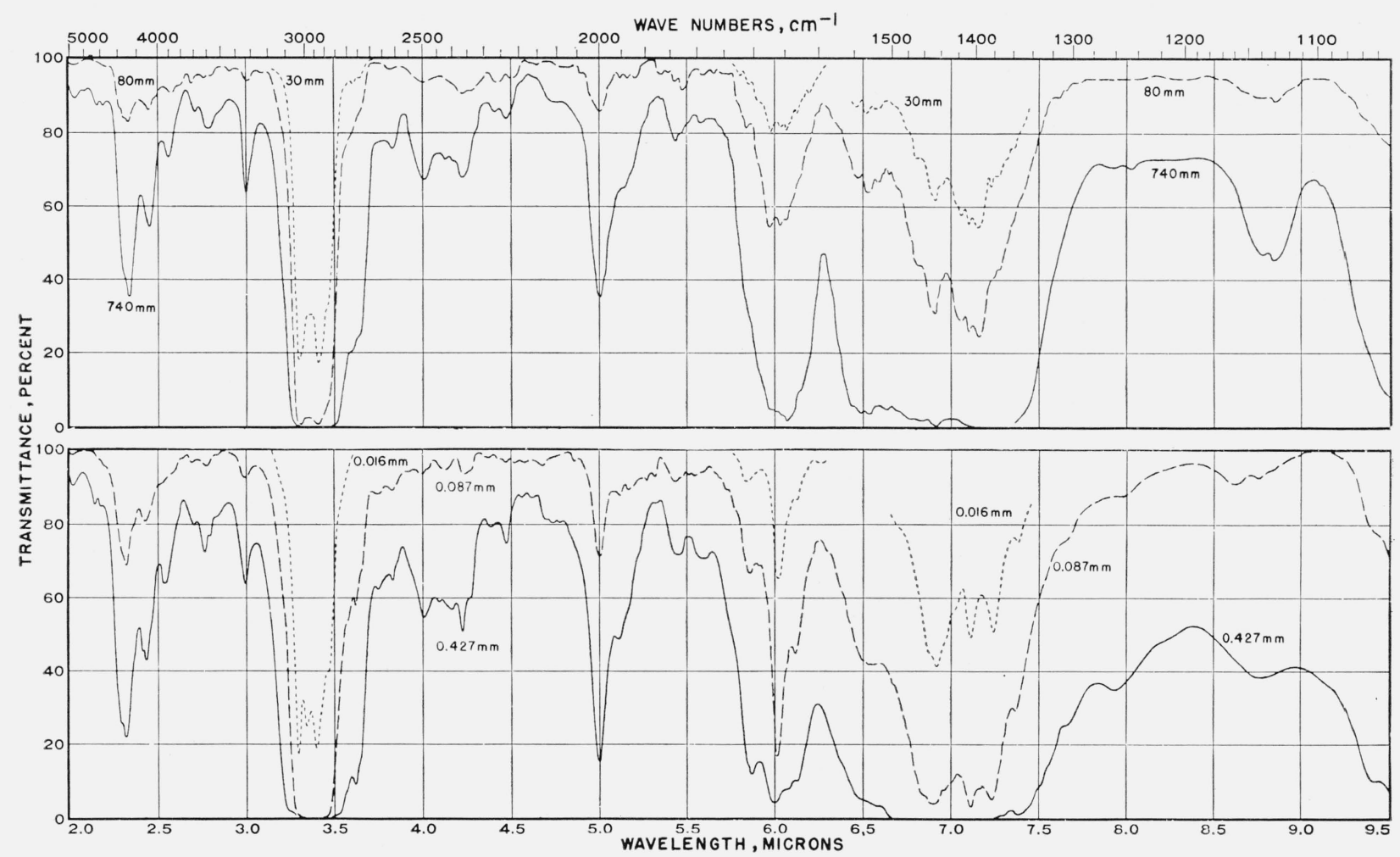

Figure 3. Infrared absorption spectrum of cis-2-butene.

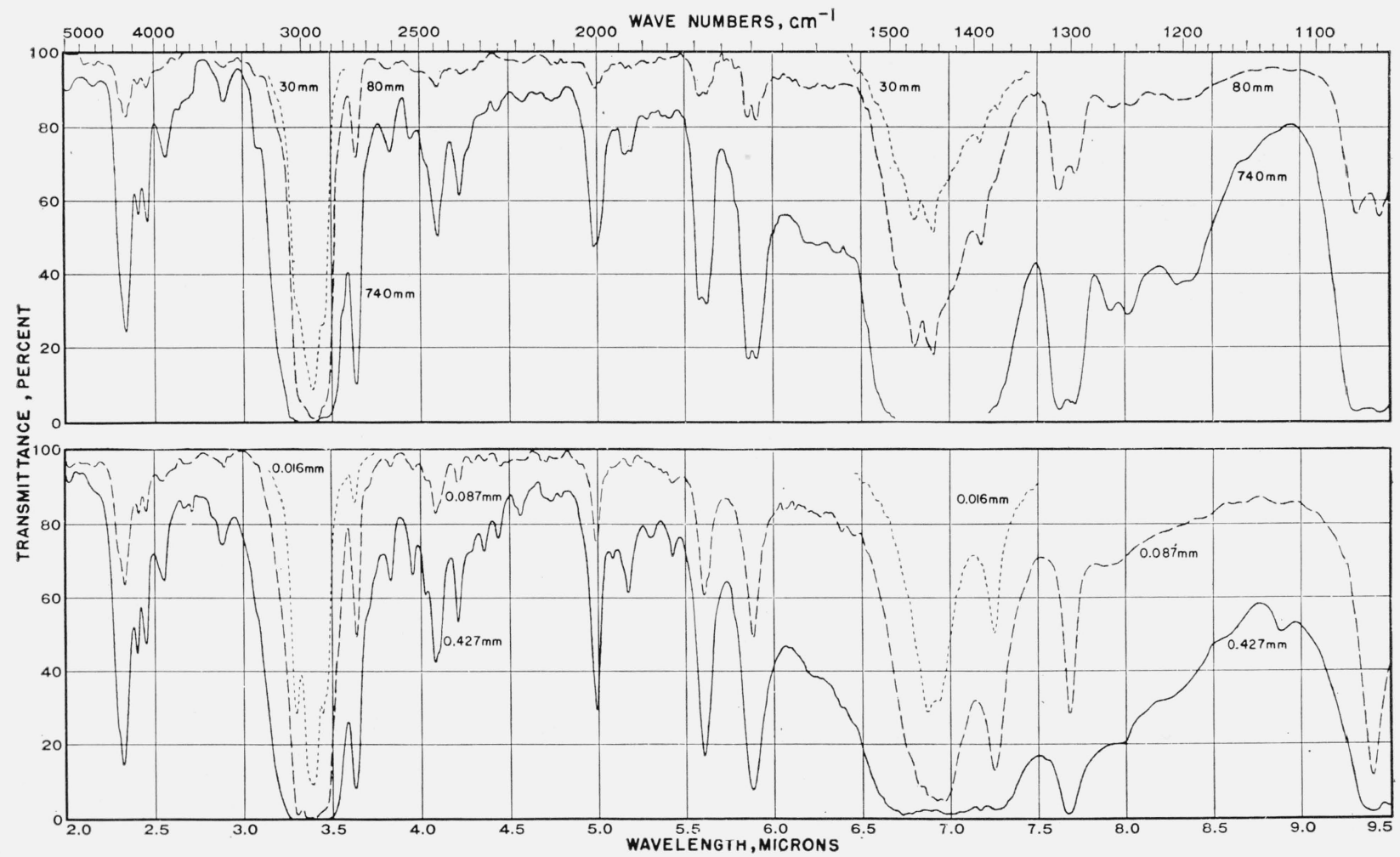

FIGURE 4. Infrared absorption spectrum of trans-2-butene. 

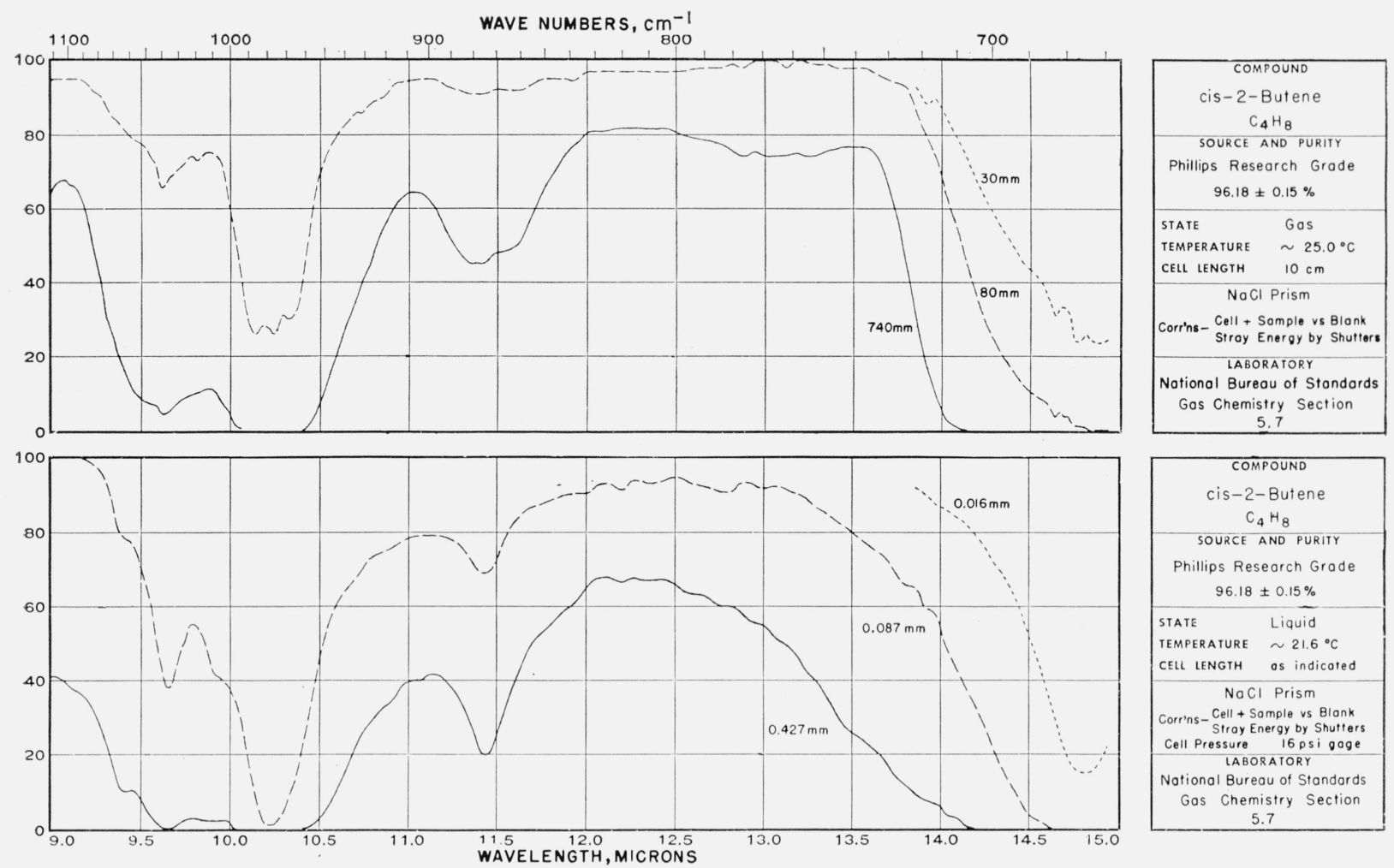

\begin{tabular}{|c|}
\hline COMPOUND \\
CIS-2-Butene \\
$\mathrm{C}_{4} \mathrm{H}_{8}$ \\
SOURCE AND PURITY \\
Phillips Research Grade \\
$96.18 \pm 0.15 \%$ \\
STATE Liquid \\
TEMPERATURE $\sim 21.6^{\circ} \mathrm{C}$ \\
CELL LENGTH os indicated \\
NaCl Prism \\
Corr'ns-Cell + Sample vs Blank \\
Stray Energy by Shutters \\
Cell Pressure 16 psi goge \\
LABORATORY \\
National Bureau of Standards \\
Gas Chemistry Section \\
5.7 \\
\hline
\end{tabular}

Figure 4 Continued.
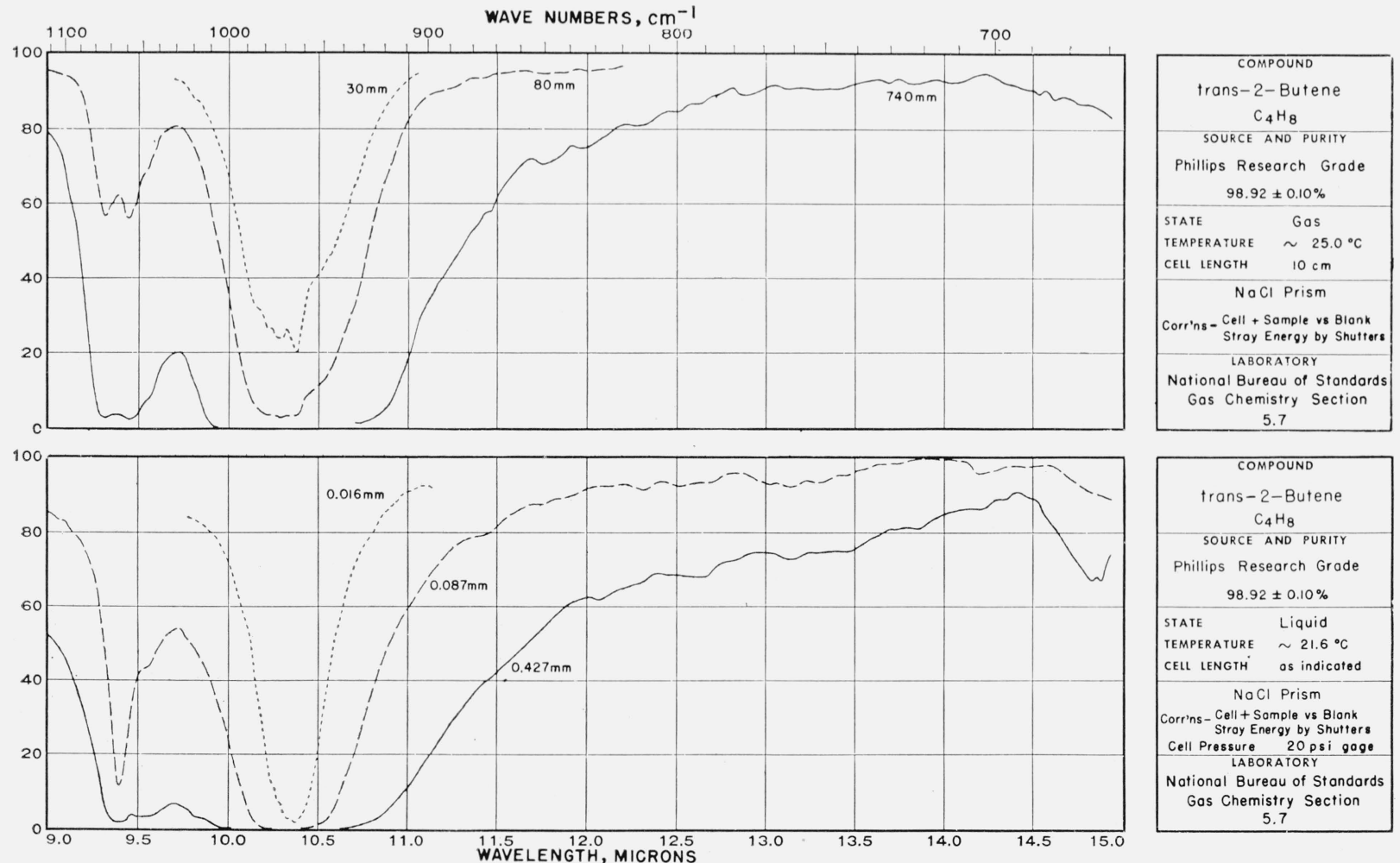

\begin{tabular}{|c|c|}
\hline trans & $\begin{array}{l}\text { POUND } \\
\text { - Butene } \\
{ }_{4} \mathrm{H}_{8}\end{array}$ \\
\hline $\begin{array}{r}\text { SOURCE } \\
\text { Phillips } R \\
98 .\end{array}$ & $\begin{array}{l}\text { AND PURITY } \\
\text { earch Grode } \\
\pm 0.10 \%\end{array}$ \\
\hline $\begin{array}{l}\text { STATE } \\
\text { TEMPERATUR: } \\
\text { CELL LENGTH }\end{array}$ & $\begin{array}{l}\text { Liquid } \\
\sim 21.6^{\circ} \mathrm{C} \\
\text { os indicoted }\end{array}$ \\
\hline $\begin{array}{r}N \\
N o \\
\text { Corr'ns- Cell }+ \\
\text { Stroy } \\
\text { Cell Pressur } \\
\text { LA } \\
\text { National B } \\
\text { Gos Che }\end{array}$ & $\begin{array}{l}\text { Prism } \\
\text { omple vs Blonk } \\
\text { ergy by Shutters } \\
20 \text { psi goge } \\
\text { RATORY } \\
\text { au of Stondards } \\
\text { stry Section } \\
5.7\end{array}$ \\
\hline
\end{tabular}

Figure 4 Continued. 


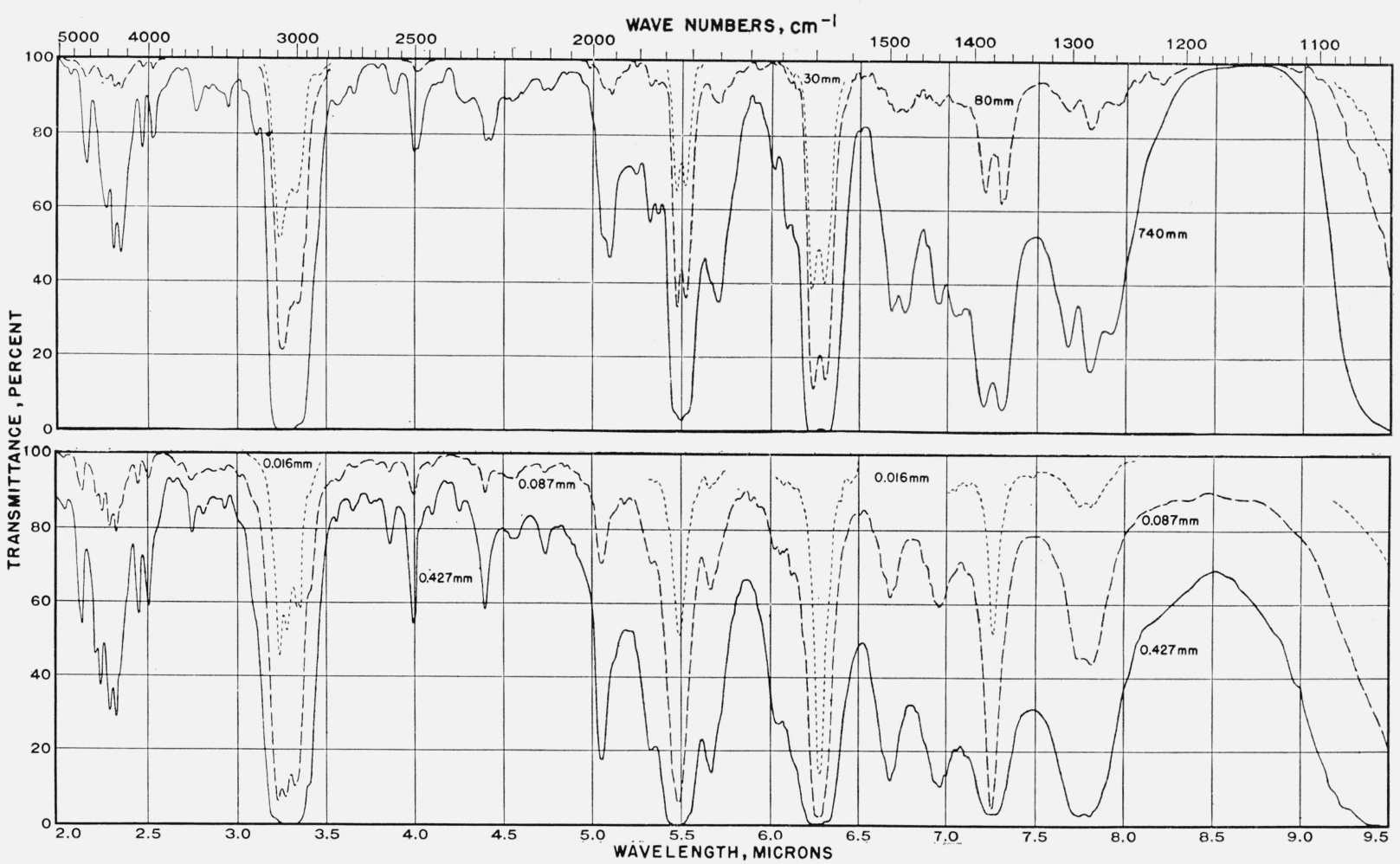

Figure 5. Infrared absorption spectrum of 1,3-butadiene.
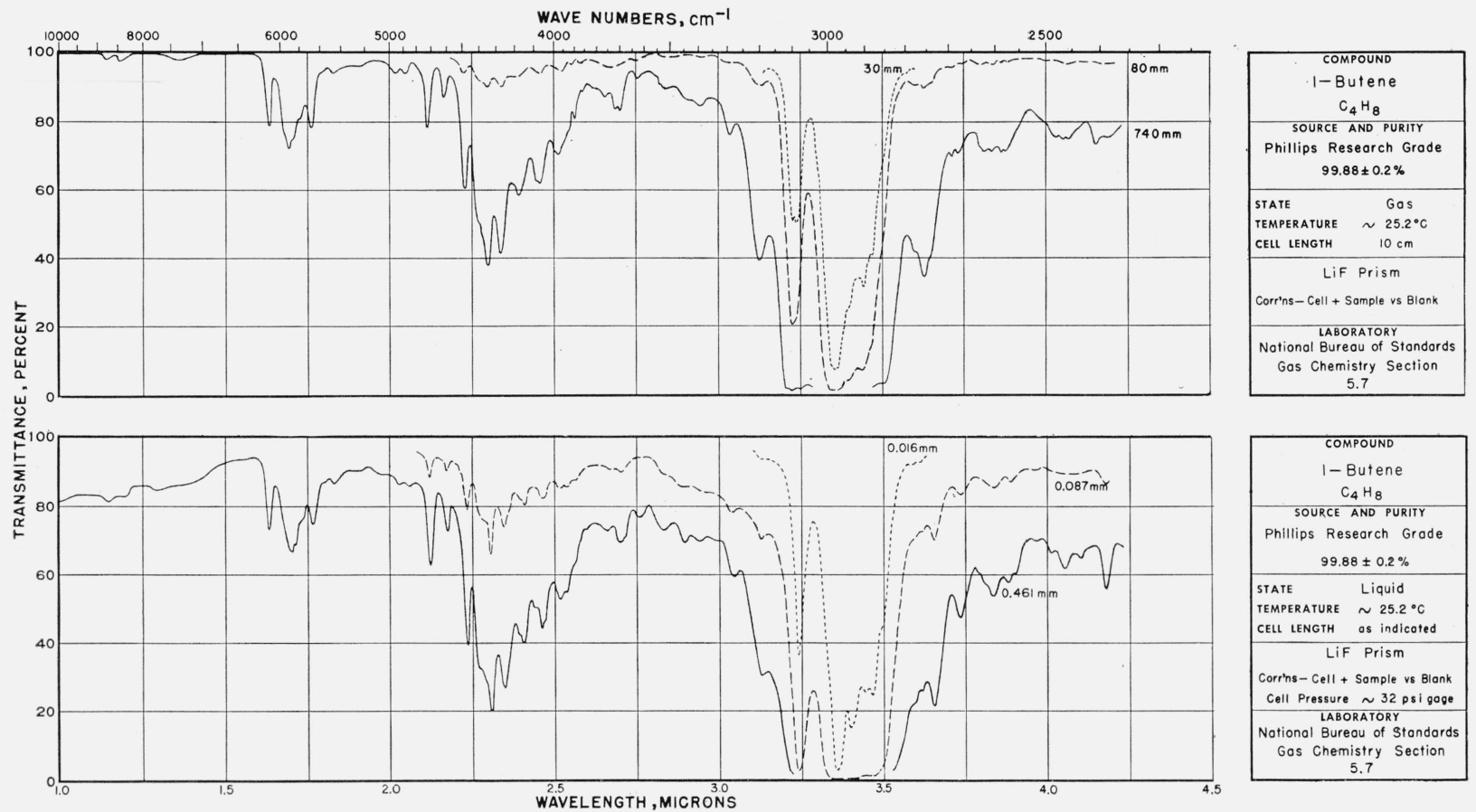

FiguRE 6. Infrared absorption spectrum of 1-butene. 

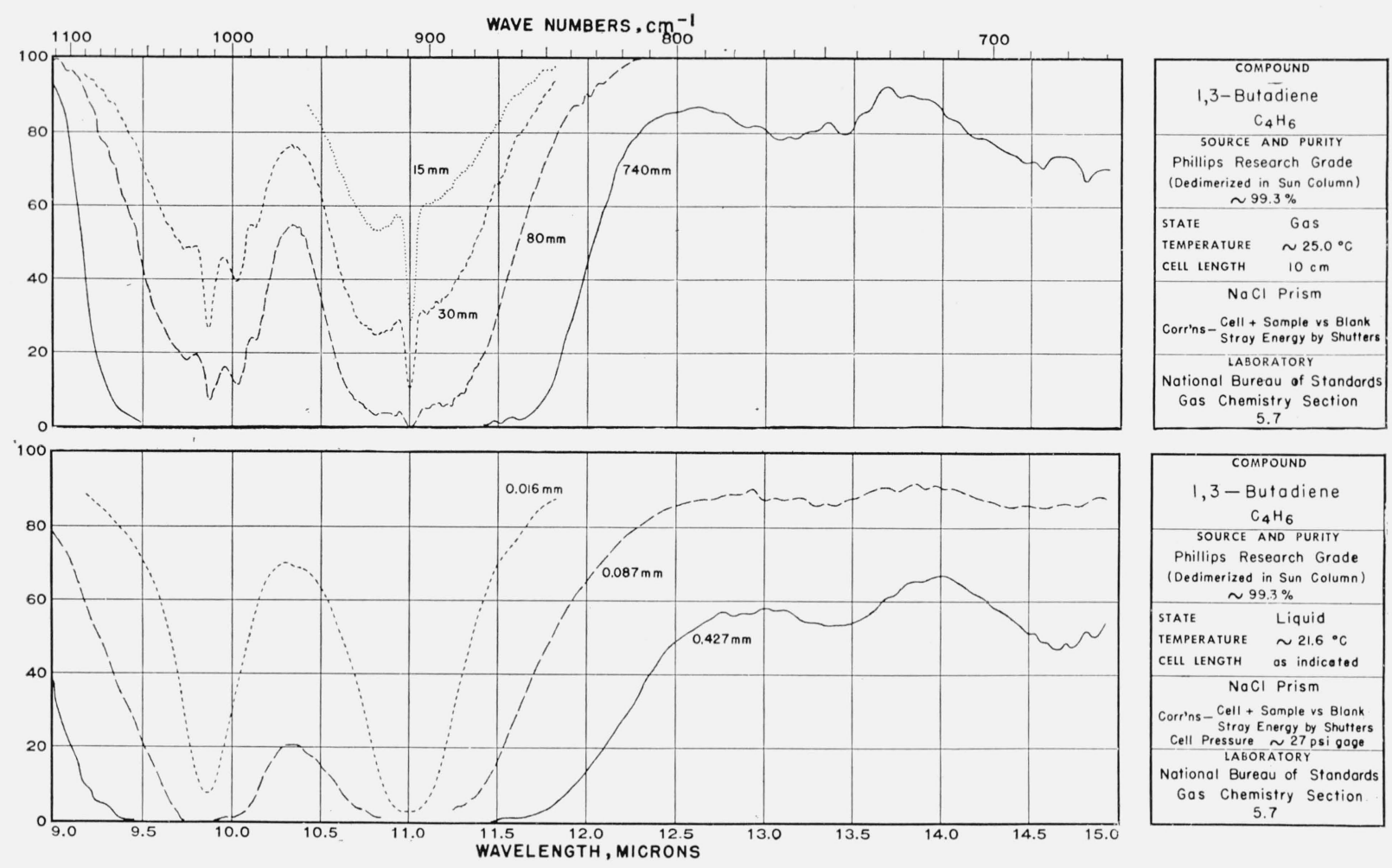

COMPOUND
1,3-Butadiene
$\mathrm{C}_{4} \mathrm{H}_{6}$
SOURCE AND PURIIY
Phillips Research Grade
(Dedimerized in Sun Column)
$\sim 99.3 \%$
STATE Liquid
TEMPERATURE $\sim 21.6{ }^{\circ} \mathrm{C}$
CELL LENGTH as indicated
NaCl Prism
Corr'ns-Cell + Sample vs Blank
Stray Energy by Shutters
Cell Pressure $\sim 27$ psi gage
LABORATORY
National Bureau of Standards
GaS Chemistry Section
5.7

Figure 6 - Continued.
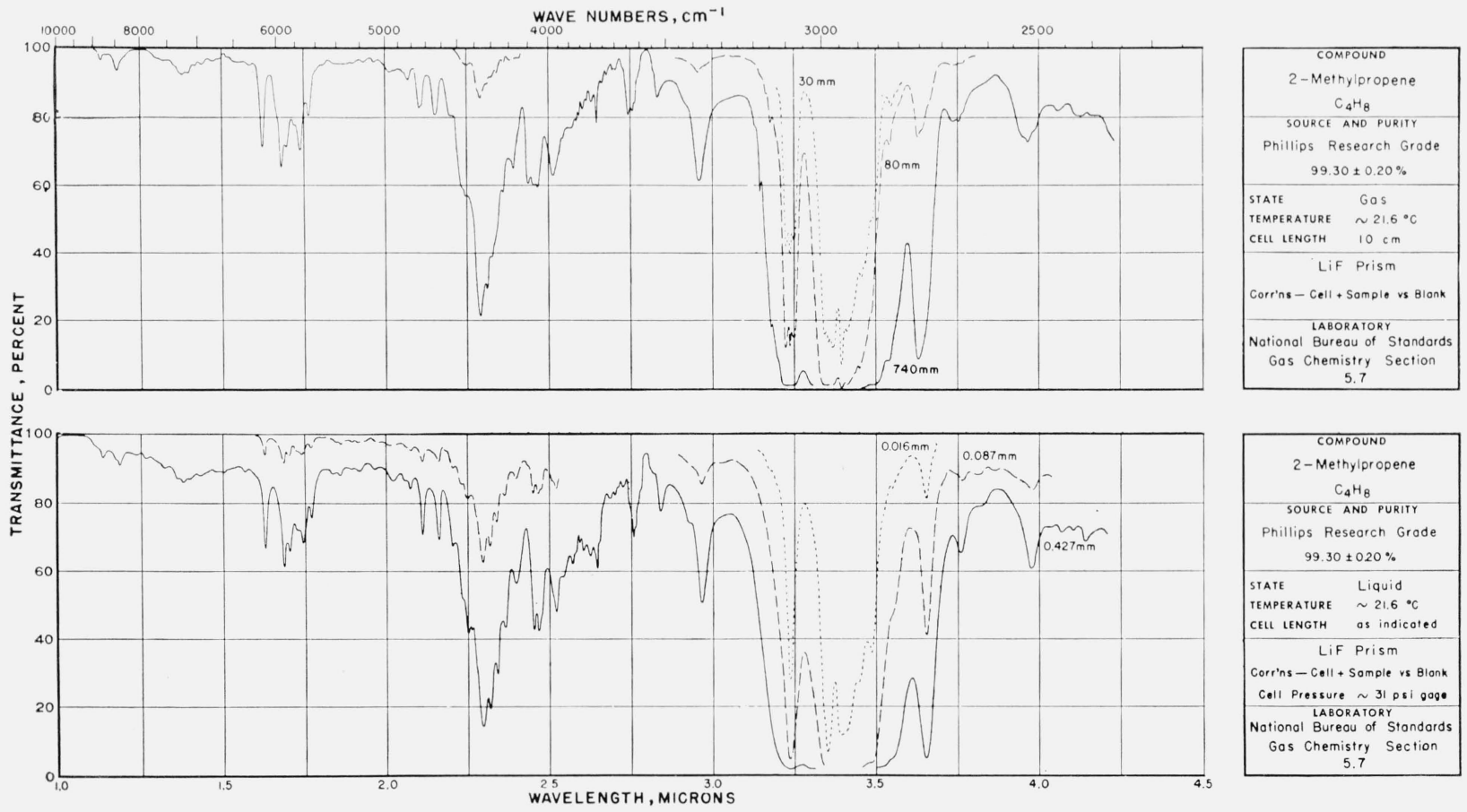

Figure 7. Infrared absorption spectrum of 2-methylpropene (isobutene). 


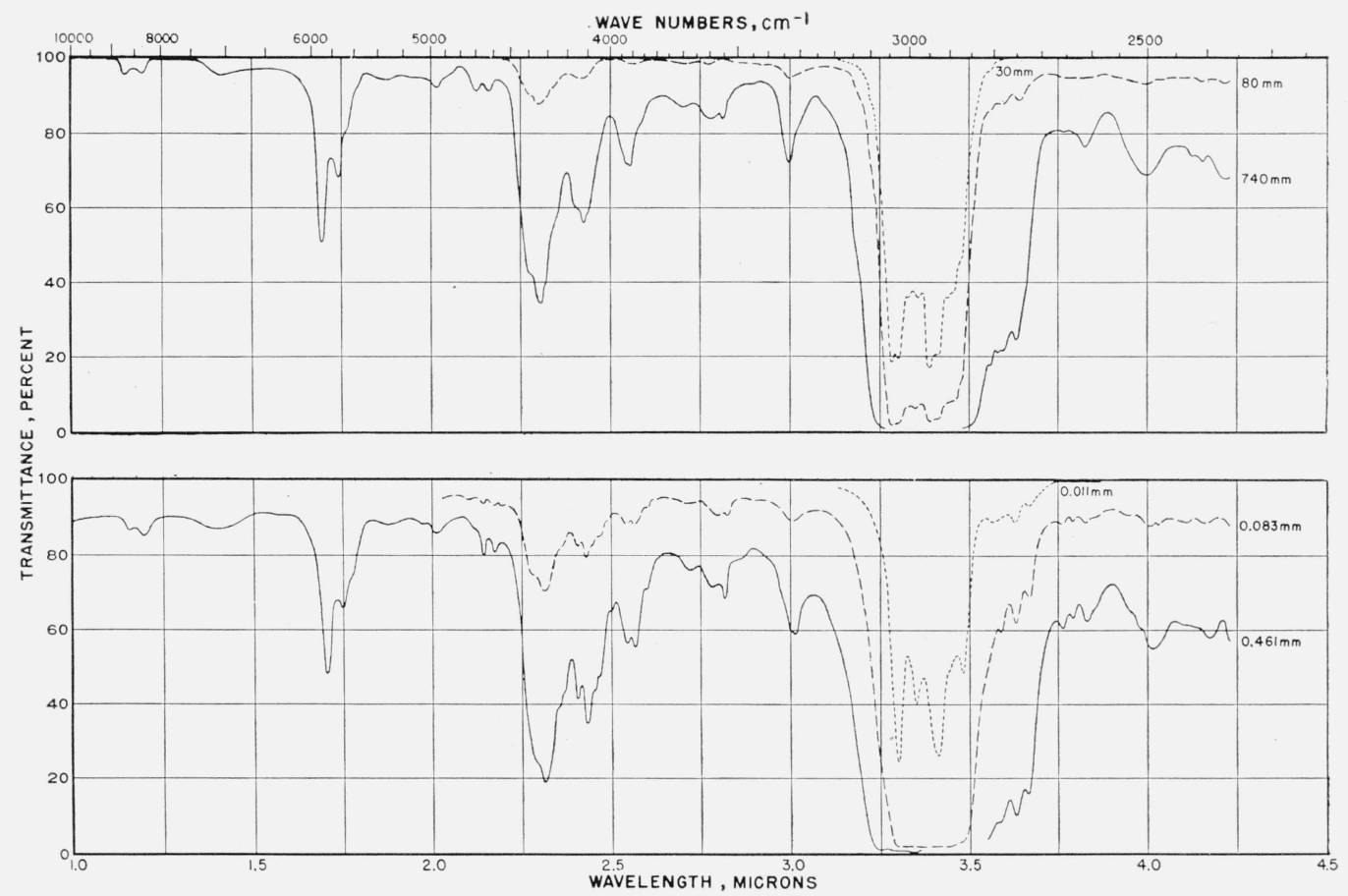

COMPOUND
Cis - $2-$ But ene
$\mathrm{C}_{4} \mathrm{H}_{8}$
SOURCE AND PURIIY
Phillips Research. Grade
$96.18 \pm 0.15 \%$

FigURE 8. Infrared absorption spectrum of cis-2-butene.
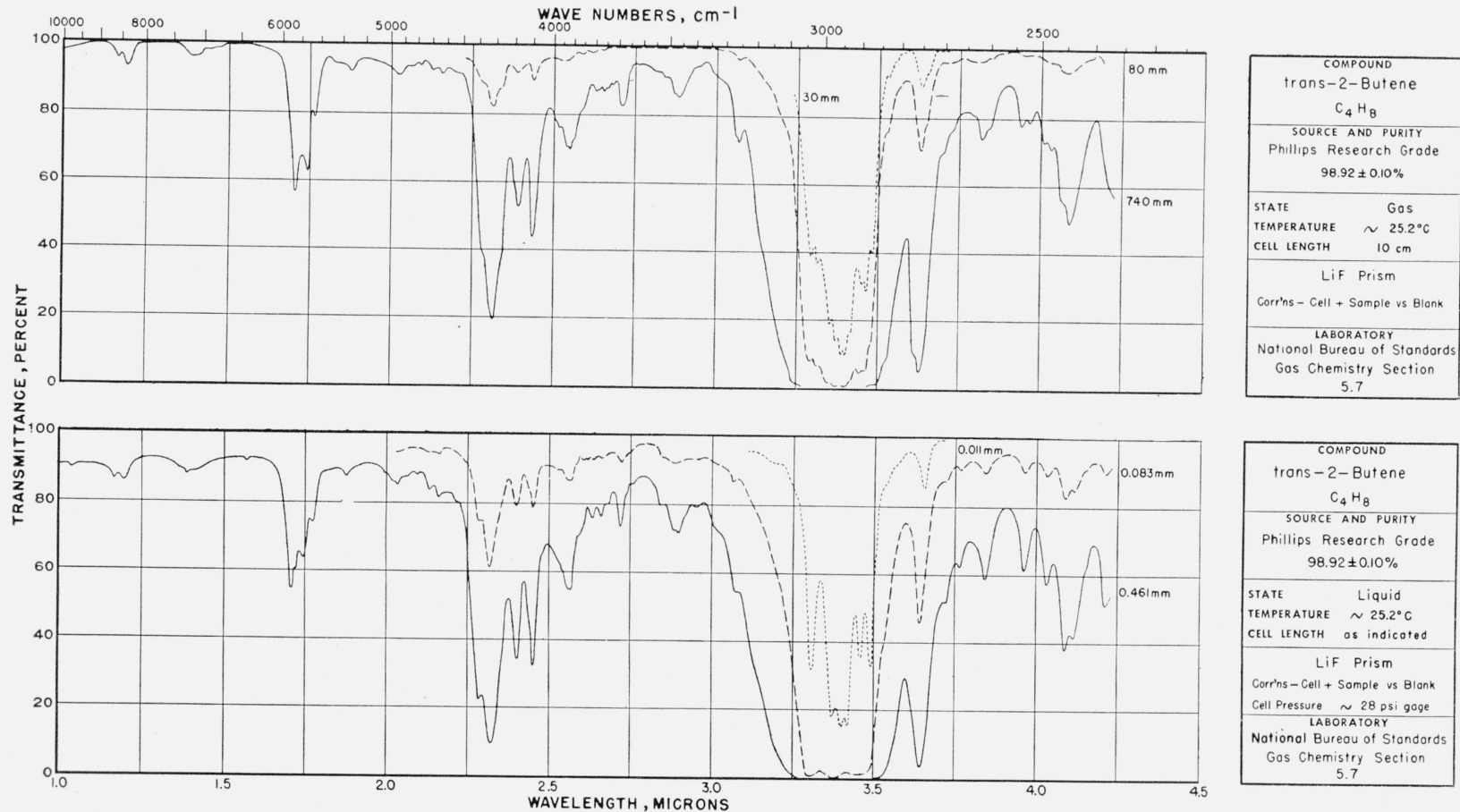

FiguRE 9. Infrared absorption spectrum of trans-2-butene. 


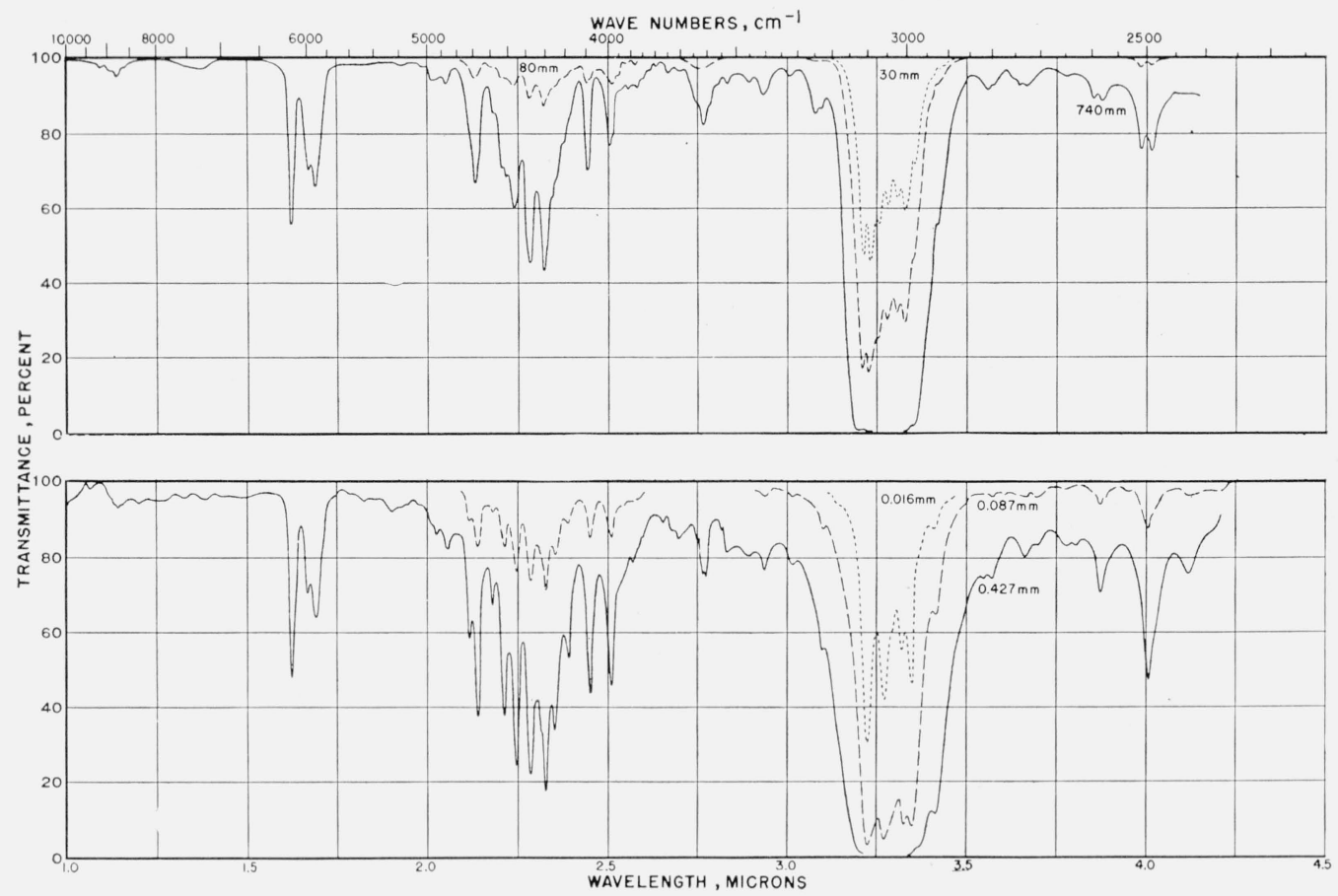

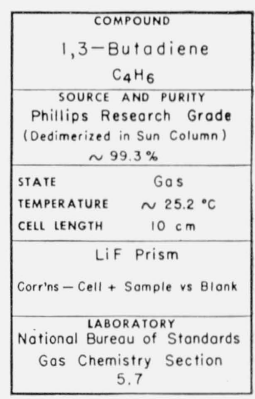

Figure 10. Infrared absorption spectrum of 1,3-butadiene.

Washington, June 6, 1949. 